\title{
HUBUNGAN PENGETAHUAN DENGAN SIKAP TERHADAP EFEK SAMPING PADA ASEPTOR KB PIL KOMBINASI DI PUSKESMAS PAL TIGA TAHUN 2018
}

\author{
Melyani $^{1}$, Yuliana $^{2}$
}

\author{
Akademi Kebidanan Panca Bhakti Pontianak \\ Email korespondensi: akbidpbpontianak@gmail.com
}

\begin{abstract}
Abstrak
Kontrasepsi KB pil kombinasi adalah pil kontrasepsi yang berisi estrogen maupun progestron yang digunakan oleh $20,71 \%$ akseptor dari total seluruh akseptor KB (Susenas,2015). Penggunaan pil kb kombinasi dapat menimbulkan mual muntah, pertambahan berat badan, perdarahan tidak teratur, retensi cairan, edema, miastalgia, sakit kepala, timbulnya jerawat, alpoesia, dan keluhan ringan lainnya. Keluhan ini berlangsung pada bulan-bulan pertama pemakaian KB pil. Berdasarkan studi pendahuluan menunjukkan bahwa jumlah akseptor KB pil dari bulan Desember 2017-Februari 2018, sejumlah 78 orang dimana 11 orang mengalami efek samping yaitu 6 orang mengalami kenaikan BB, 3 orang pusing, dan 2 spotting. Hasil wawancara yang dilakukan oleh peneliti terhadap 10 orang akseptor pil KB kombinasi didapatkan bahwa dari 10 orang akseptor, 7 orang mengetahui tentang isi pil atau bentuk dari KB pil kombinasi. Tujuan penelitian ini adalah mengetahui Hubungan antara Pengetahuan tentang Akseptor KB Pil Kombinasi dengan Sikap Terhadap Efek Samping Di Puskesmas Pal Tiga tahun 2018. Metode penelitian yang digunakan adalah analitik korelasi, dengan pendekatan cross sectional. Sampel pada penelitian ini adalah 78 responden. Hasil penelitian yang diperoleh yaitu sebagian dari responden 55 akseptor (70\%) berpengetahuan kurang, dan sebagian kecil dari responden yaitu 6 orang (7\%) berpengetahuan baik. sikap akseptor KB pil kombinasi yang mendukung didapatkan 24 responden (31\%), dan sikap akseptor KB pil kombinasi yang tidak mendukung sebesar 54 responden (69\%). Dapat disimpulkan bahwa ada hubungan yang signifikan antara pengetahuan akseptor KB pil kombinasi dengan sikap terhadap efek samping di Puskesmas Pal Tiga tahun 2018. Saran bagi puskesmas pal tiga perlunya untuk meningkatkan pelayanan kebidanan tentang KB Pil kombinasi dengan pemberian informasi dapat dilakukan melalui penyuluhan serta konseling tentang efek samping yang terjadi. Bagi akseptor KB pil kombinasi diharapkan untuk meningkatkan pengetahuan tentang kontrasepsi yang digunakan dan harus mengetahui bagaimana cara menyikapi efek samping yang terjadi.
\end{abstract}

Kata Kunci: Pengetahuan, Sikap, peraawatan Payudara

\section{Pendahuluan}

Pil KB merupakan salah satu kontrasepsi Indonesia, dimama $47,54 \% \mathrm{~Kb}$ suntik, $29,58 \%$ hormonal yang bertujuan untuk mencegah terjadinya kehamilan yang ditambahkan ke dalam pil, 11.07\% IUD, 10,46\% implan, 3,52\% MOW, tubuh seorang wanita dengan cara diminum (pil) 3,15 kondom dan hanya 0,69\% MOP (Depkes RI, 2014).

Tujuan dari konsumsi pil KB adalah untuk mencegah, menghambat dan menjarangkan terjadinya kehamilan yang memang tidak diinginkan. Untuk itu kepatuhan mengkonsumsi pil KB secara teratur sesuai dengan dengan petunjuk tenaga kesehatan harus dilakukan. Kontrasepsi hormonal menduduki peringkat pertama pada penggunaan kontrasepsi di

Berdasarkan sisi medis, alat kontrasepsi non hormonal jauh lebih aman bagi kesehehatan tubuh dibanding dengan kontrasepsi hormonal yang akan menggangu keseimbangan hormonal pada pengguna jangka panjang, namu myoritas pengguna kontrasepsi di Indonesia masih terarah pada kontrasepsi hormonal yang terdiri dari hormon estogen dan progesteron atau kombinasi

\footnotetext{
${ }^{1}$ Dosen Akademi Kebidanan Panca Bhakti Pontianak

${ }^{2}$ Dosen Akademi Kebidanan Panca Bhakti Pontianak
} 
dinilai sangat efektif dalam mencegah kehamilan bidaa dibandingkan dengan kontrapsi non hormonal (siswosudarmono et al, 209). Pengguanan pil kb kombinasi dapat menimbulkan mual muntah, pertambahan berat badan, perdarahan tidak teratur, retensi cairan, edema, miastalgia, sakit kepala, timbulnya jerawat, alpoesia, dan keluhan ringan lainnya. Keluhan ini berlangsung pada bulan-bulan pertama pemakaian KB pil.

Efek samping yang berat seperti terjadi trombo-embolisme, mungkin karena terjadi peningkatan aktivitas faktor-faktor pembekuan atau karena pengukuran vaskuler secara langsung (Irianto, 2014). Sesuai dengan penilitian Sujono tahun 2013 tentang "Pengaruh Pemakaian Kontrasepsi terhadap Peningkatan Tekanan Darah Wanita Di Puskesmas Sungai Duri di Kabupaten Magelang" diketahui bahwa terjadi peningkatan tekanan darah sistolik pada akseptor KB pil dengan lama penggunaan 1-5 tahun sebesar 10-30 $\mathrm{mmHg}$.

Berdasarkan studi pendahuluan menunjukkan bahwa jumlah akseptor KB pil dari bulan Desember 2017-Februari 2018, sejumlah 78 orang dimana 11 orang mengalami efek samping yaitu 6 orang mengalami kenaikan BB, 3 orang pusing, dan 2 spotting. Hasil wawancara yang dilakukan untuk peneliti terhadap 10 orang akseptor pil KB kombinasi didapatkan bahwa dari 10 orang akseptor, 7 orang mengetahui tentang isi pil atau bentuk dari KB pil kombinasi dan cara mengkonsumsinya namun belum mengetahui efek samping dari pil KB tersebut. Dari 10 akseptor diketahui 5 orang mengalami efek samping kenaikan berat badan, 3 akseptor mengalami flek/spotting, dan 2 mengalami pusing. Dari 10 akseptor yang mengalami efek samping 7 akseptor tetap menggunakan dan 3 akseptor berencana memilih kontrasepsi lain.

Dari 10 akseptor KB pil kombinasi sikap yang dilakukan untuk mengatasi efek samping seperti pusing, kenaikan $\mathrm{BB}$, dan flek/spotting adalah dengan cara mengkonsumsi obat paracetamol untuk meredakan pusing, ada yang mengkonsumsi teh pelangsing untuk menangani kenaikan berat badan, dan yang mengalami flekflek hanya melakukan pemeriksaan ketenaga kesehatan dengan diberikan penjelasan kepada ibu bahwa flek-flek yang terjadi merupakan efek samping dari pemakaian pil KB kombinasi.

\section{Metode}

Penelitian ini menggunakan jenis penelitian observasional Analitik dengan pendekatan secara Crossectional. Penelitian dilaksanakan pada bulan Februari sampai bulan Juni tahun 2018 di Puskesmas Pal III. Populasi penelitian yaitu semua ibu yang menggunakan Pil kombinasi di Puskesmas Pal III sebanayak 78 responden. Sampel dalam penelitian ini menggunakan total sampling yaitu 78 responden. Pengumpulan data menggunakan kemudian diolah dan dianalisis menggunakan analisa univariat serta analisi bivariat menggunakan uji square.

\section{Hasil dan Pembahasan}

Tabel 1:Pengetahuan Responden

\begin{tabular}{ccc}
\hline Penegetahuan & $\mathrm{n}$ & $\%$ \\
\hline Baik & 6 & 8
\end{tabular}




\begin{tabular}{lll}
\hline Cukup & 17 & 22 \\
Kurang & 55 & 70 \\
\hline
\end{tabular}

Dari tabel di atas dapat disimpulkan pengetahuan responden 55 orang (70\%) sebagian besar berpengetahuan kurang tentang pil KB kombinasi, dan sangat sedikit dari responden yaitu 6 orang (8\%) berpengetahuan baik tentang pil KB kombinasi.

Tabel 2:Sikap Responden

\begin{tabular}{ccc}
\hline Sikap terhadap efek samping & $\mathrm{n}$ & $\%$ \\
\hline Mendukung & 24 & 31 \\
Tidak Mendukung & 54 & 69 \\
\hline
\end{tabular}

Dari tabel di atas dapat disimpulkan sikap akseptor terhadap efek samping sebagian kecil responden yaitu 24 (31\%) mendukung, dan sebagian besar dari responden 54 (69\%) tidak mendukung

Tabel 3: Analisis Bivariat

\begin{tabular}{|c|c|c|c|c|c|c|}
\hline \multirow[t]{3}{*}{ Variabel } & \multicolumn{4}{|c|}{ Sikap } & \multirow{3}{*}{$\mathrm{X}^{2}$} & \multirow{3}{*}{ P Value } \\
\hline & \multicolumn{2}{|l|}{ Mendukung } & \multicolumn{2}{|c|}{$\begin{array}{c}\text { Tidak } \\
\text { mendukung }\end{array}$} & & \\
\hline & $\mathrm{N}$ & $\%$ & $\mathrm{~N}$ & $\%$ & & \\
\hline \multicolumn{7}{|l|}{ Pengetahuan } \\
\hline Baik & 6 & 7,7 & 0 & 0 & 39,6 & \\
\hline Cukup & 12 & 15,3 & 4 & 5,1 & & \\
\hline Kurang & 6 & 7,7 & 50 & 64,3 & & \\
\hline
\end{tabular}

Berdasarkan dari tabel di dapat bahwa pengetahuannya kurang $7,7 \%$ memiliki sikap tidak mendukung 50\%. Analisis bivariat dengan menggunakan Chi-Squere diperoleh hasil nilai $x^{2}$ tabel (5.991) dan nilai $x^{2}$ hitung 39,3 sehingga ada hubungan antara pengetahuan akseptor $\mathrm{KB}$ pil kombinasi dengan sikap terhadap efek samping di Puskesmas Pal Tiga tahun 2018. Dari beberapa hal diatas dapat dilihat bahwa tidak cukup dengan pengetahuan baik saja yang dimiliki oleh akseptor KB pil kombinasi untuk mempengaruhi sikap akseptor terhadap efek samping yang terjadi sehingga harus didukung oleh kesadaran akseptor KB pil kombinasi.
Pengetahuan tentang KB pil kombinasi adalah pil kontrasepsi yang berisi estrogen maupun progestron atau progesteron (progestagen, grestagen). Penelitian ini sependapat dengan hasil penelitian Purwaningsih, 2014 tentang Pengetahuan Akseptor Kontrasepsi Pil Kombinasi di Desa Karang Kecamatan Delanggu Kabupaten Klaten didapatkan bahwa penggunakan pil kombinasi sebesar 55 akseptor. Dari 55 akseptor pengguna KB pil kombinasi sebagian besar responden paling banyak yaitu sebanyak 25 akseptor $(45,5 \%)$ dengan pengetahuan cukup tentang kontrasepsi pil oral kombinasi, 24 akseptor $(43,6 \%)$ dengan pengetahuan baik dan responden paling sedikit adalah dengan 
pengetahuan kurang sebanyak 6 orang $(10,9 \%)$.

Hal ini sejalan dengan hasil penelitian Pradila tahun 2013 yang berjudul tentang "Tingkat Pengetahuan Kontrasepsi Pil di BPS Widjiati Margomulyo Bojonegoro" menunjukan bahwa pengetahuan akseptor tentang kontrasepsi pil oral kombinasi sebagian besar baik yaitu 18 responden. Hal tersebut dapat dipengaruhi oleh pengalaman ibu dalam menggunakan kontrasepsi pil oral kombinasi dalam waktu yang cukup lama. Dilihat dari pengalaman pada saat pemakaian KB pil kombinasi yang sudah lama didapatkan oleh peneliti bahwa sikap dari akseptor tentang kontrasepsi pil oral kombinasi sebagian besar memilih pindah ke akseptor lain yaitu 4 responden.

Hal tersebut dikarenakan pengetahuan seseorang tentang sesuatu hal akan mempunyai sikapnya. Sikap positif maupun negatif tergantung dari pemahaman individu tentang suatu hal tersebut. Sehingga sikap ini selanjutnya akan mendorong individu melakukan perilaku tertentu pada saat dibutuhkan tetapi jika sikapnya negatif justru akan menghindari untuk melakukan perilaku tersebut (Patmawati, 2010). Hubungan pengetahuan akseptor $\mathrm{KB}$ pil kombinasi dengan sikap terhadap efek samping yaitu akseptor mendapatkan informasi dari pelayanan di puskesmas yang memberikan penjelasan tentang pentingnya mengetahui $\mathrm{KB}$ pil kombinasi. Pengetahuan merupakan indikator seseorang dalam melakukan tindakan, yaitu akseptor $\mathrm{KB}$ tahu tentang $\mathrm{KB}$ pil kombinasi dan memahami betapa pentingnya mengetahui bagaimana sikap terhadap efek samping yang terjadi.

\section{Kesimpulan}

Berdasarkan hasil penelitian yang telah di lakukan maka dapat disimpulkan Pengetahuan akseptor KB pil kombinasi sebagian dari responden yaitu 55 akseptor (70\%) berpengetahuan kurang. Sikap akseptor KB pil kombinasi yang tidak mendukung didapatkan 54 responden (69\%). Dan dapat disimpulkan ada hubungan yang signifikan antara pengetahuan akseptor KB pil kombinasi dengan sikap terhadap efek samping di Puskesmas Pal Tiga tahun 2018 dilihat dari nilai $x^{2}$ tabel (5.991) dan nilai $x^{2}$ hitang 39,3.

Saran bagi puskesmas pal tiga perlunya untuk meningkatkan pelayanan kebidanan tentang KB Pil kombinasi dengan pemberian informasi dapat dilakukan melalui penyuluhan serta konseling tentang efek samping yang terjadi. Bagi akseptor KB pil kombinasi diharapkan untuk meningkatkan pengetahuan tentang kontrasepsi yang digunakan dan harus mengetahui bagaimana cara menyikapi efek samping yang terjadi.

\section{Daftar Pustaka}

Agnesa, A. 2010. Makalah Pil Kontrasepsi (Pil KB). $\quad$ http://KesmasUnsoed.blogspot.com. Diakses: 27 Februari 2018, 14.55 WIB

Arikunto. 2006. Manajemen Penelitian. Rineka Cipta: Jakarta 2007. Metode Penelitian. Fitramaya: Jakarta 
2010. Manajemen Penelitian. Rineka Cipta: Jakarta.

Azwar. 2013. Komponen Sikap. Rineka Cipta: Jakarta

. 2012. Perubahan Sikap. Rineka Cipta: Jakarta

Bararah. 2011. Efek Samping Pil KB. Pustaka Rihama: Yogyakarta

Corwin. 2009. Efek Samping Dalam Kontrasepsi. Graha Ilmu. Jakarta

Effendi, F \& Makhfudli. 2009. Keperawatan Kesehatan Komunitas: Teori dan Praktek Dalam Keperawatan. Jakarta: Salemba medika

Fitriani, Sinta. 2011. Promosi Kesehatan. Yogyakarta: Graha Ilmu

Hartanto. 2016. Analisis data kependudukan dan $\mathrm{Kb}$ hasil Susenas 2015 Jakarta: Rakomas

2004. Keluarga Berencana dan Kontrasepsi. Jakarta: Pustaka Sinar

Hartono. 2004. Efek Samping KB Pil. Bandung: Alvabeta

Harianto, 2005. Risiko penggunaan pil kkombinasi terhadap kejadian kanker payudara pada akseptor KB di perjan RS Dr.Cipto Mangunkusumo. http://psr.ui.ac.id/index.php/journal. Diakses: 27 Februari 2018, 13.27 WIB

Handayani, Sri. 2010. Buku Ajaran Pelayanan Keluarga Berencana. Pustaka Rihama: Yogyakarta.

Hidayat, A. 2014. Metode Penelitian Dan Teknik Analisis Data. Selamba Medika: Jakarta

Irianto, Koes. 2014. Pelayanan Keluarga Berencana. Bandung: Alvabeta

Indreswari. 2014. Faktor yang mempengaruhi pengetahuan seseorang. http://docplayer.info/63188235-Unnesjournal-of-public-health.html. Diakses: 28 Februari 2018, 13.45 WIB

Icoel. 2012. Keluarga Berencana Jenis kontrasepsi http://repository.unimus.ac.id/883/3/BA
B\%202.pdf. Diakses: 27 Februari 2018, $15.34 \mathrm{WIB}$

Kementrian kesehatan Indonesia, 2014. Profil Kesehatan Indonesia tahun 2014.http://kalbar.bkkbn.go.id/SiteColl ectionDocuments/Analisis\%20Data\%2 0Kependudukan\%20dan\%20KB.

Diakses: 28 Februari 2018, 12.13 WIB

Kelman. 2012.Metodologi Penelitian Perubahan

sikap.http://digilib.unila.ac.id/4607/15/ BAB\%20II.pdf. Diakses: 28 Februari 2018, 16.43 WIB

Luthfi, Muh. 2015. Peseta Kb Dikalimantan Barat. BKKBN: Kalbar. http://www.kependudukankalbar.com/p eserta-kb-di-kalimantan-barat.html. Diakses: 3 Maret 2018, 11.40 WIB

Mubarak W I, 2011. Promosi Kesehatan untuk Kebidanan. Jakarta: Penerbit Salemba Medika

Machfoedz, Ircham. 2014. Metodologi Penelitian. Fitramaya: Yogyakarta

2010. Metodologi Penelitian. Fitramaya: Yogyakarta.

Notoatmodjo, S. 2003. Ilmu Kesehatan Masyarakat. Rineka Cipta: Jakarta

2005. Metodologi Penelitian Kesehatan. Rineka Cipta: Jakarta

2010. Metodologi Penelitian Kesehatan. Rineka Cipta: Jakarta

2012. Metodologi Penelitian Kesehatan. Rineka Cipta: Jakarta

Purwaningsih, Endah. 2011. Hubungan Pengetahuan Akseptor Kb Pil Oral Kombinasi Dengan Kepatuhan Dalam Mengkonsumsi $\mathrm{Kb} \quad$ Pil. http://ejournal.stikesmukla.ac.id, Diakses: 27 Februari 2018, 13.45 WIB

Pradila, Eviratna. 2013. Tingkat Pengetahuan Akseptor Kontrasepsi Pil Tentang Efek Samping Kontrasepsi Pil Di Bps Widjiati Margromulyo Bojonegoro. 
http://digilib.stikeskusumahusada.ac.id. Diakses: 10 Maret 2018, 16.35 WIB

Prasetyawati, Anna. 2012. Hubungan Pengetahuan Akseptor Tentang Kontrasepsi Pil Oral Kombinasi Dengan Kepatuhan Dalam Mengkonsumsi Pil $\mathrm{Kb}$ Di Wilayah Desa Margasana Kecamatan Jatilawang Tahun 2012.Http://download.portalgaruda.org/ article.php?, Diakses: 3 Maret 2018, 11.45 WIB

Riyanto dan Budiman. 2013. Faktor yang mempengaruhi pengetahuan seseorang. Jakarta: Salemba Medika

mempengaruhi pengetahuan seseorang.http://repository.umy.ac.id/bi tstream/handle/123456789/7350/BAB $\% 20 I I$.pdf? sequence $=6 \&$ isAllowed $=\mathrm{y}$. Diakses: 27 Februari 2018, 12.35 WIB

Saifuddin, AB. 2010. Buku Panduan Praktis Pelayanan Kontrasepsi. Jakarta: Bina Pustaka Sarwono Prawirohardjo

Susenas, 2016, Analisis Data Kependudukan dan KB Hasil Susenas 2015, Jakarta: http://www.kependudukankalbar.com/a nalisis-data-kependudukan-dan-kbhasil-susenas-2015.html. Diakses: 27 Februari 2018, 14.35 WIB

Siti. 2013. Dampak dari penggunaan alat kontrasepsi KB pil di BPS Ertin. http://stikesmuhla.ac.id/wpcontent/uplo ads/jurnalsurya/noXVIII/16-23-RatihIndah.pd. Diakses : 27 Februari 2018, 13.44 WIB
Sujono. 2013. Pengaruh pemakaian kontrasepsi terhadap peningkatan tekanan darah wanita di puskesmas sungai duri kabupaten magelang. http://jurnal.unpad.ac.id/ijcp/article/vie w/12702, diakses: 27 Februari 2018, $14.55 \mathrm{WIB}$

Sutarjo, Untung Suseno. 2016. Profil kesehatan indonesia. Kemenkes RI: Jakarta.http://www.depkes.go.id, Diakses: 3 Maret 2018, 09.25 WIB

Supriyantoro. 2014. Profil Kesehatan Indonesia Tahun 2013. Kemenkes RI:Jakarta.http://www.depkes.go.idf. Diakses: 3 Maret 2018, 09.30 WIB

Sunyoto, Danang. 2013. Statistik Kesehatan. Nuha Medika: Yogyakarta

Saifuddin, Abdul Bari. 2010. Buku Panduan Praktik Pelayanan Kontrasepsi. Bina Pustaka: Jakarta

Siswanto. 2014. Metodologi Penelitian Kesehatan Dan Kedokteran. Bursa Ilmu: Yogyakarta.

Sugiyono. 2010. Statistika Untuk Penelitian. Alfabeta: Bandung 2011. Statistika Untuk Penelitian. Alfabeta: Bandung

Viola. 2012. Efek Samping KB pil. Pustaka Rihama. Yogyakarta

Wawan Dan Dewi M. 2010. Teori \& Pengukuran Pengetahuan, Sikap, Dan Perilaku Manusia. Rineka Cipta: Yogyakarta 